\title{
ПЕРЕПИСИ НАСЕЛЕНИЯ В ТАТАРО-БАШКИРСКОМ ПОГРАНИЧЬЕ: ПОЛИТИЗАЦИЯ ЭТНОСТАТИСТИКИ*
}

\begin{abstract}
В статье анализируется этническая статистика Республики Башкортостан на основе данных последних трех переписей населения-1989, 2002 и 2010 г2., а также микропереписей населения 1994 и 2015 г2. Дается характеристика демографических, информачионных, административных, идеологических факторов, влияющих на итоги переписей. Делается вывод, что между татарами и башкирами в западной Башкирии нет этнокультурных различий, водораздел проходит только на уровне самосознания людей. Однако сами переписи всегда создают чрезмерную межэтническую напряженность, нагнетание негативных стереотипов, а также информаџионное противоборство сторон в СМИ и соииальных сетях, которые по форме напоминают канун избирательных кампаний, когда те или иные общественно-политические силь борются за голоса избирателей. Безусловно, это информационное противостояние во время переписей негативно сказывается в целом на межнациональном климате в республике. По мнению автора, именно по причине излишней политизащии и применения административного ресурса официальнье итоги переписей не совсем адекватно отражают объективные этническую картину и этнодемографические прочессы в регионе. В статье предлагаются конкретные практические меры для смягчения напряженности во время проведения переписей.
\end{abstract}

Ключевые слова: этностатистика, переписи населения, этнические группы, этническая граница, этническое самосознание, идентичность, естественное и механическое движение населения

Ссылка при цитировании: Габдрафиков И.М. Переписи населения в татаро-башкирском пограничье: политизация этностатистики // Вестник антропологии, 2021. № 3. С. 17-23.

Регионы современной России, в первую очередь, национально-территориальные образования в ее составе, имеют не только свои особенности этнического состава населения и этнодемографического развития, но и специфику статистического учета как численности самих этнических групп, так и языкового состава населения. Одной из таких республик, где этностатистика еще в советскую эпоху в значительной степени была политизирована, а в постсоветское время стала одним важнейших факторов региональной политики является Республика Башкортостан. Анализ ситуаций в Башкирии

Габдрафиков Ильдар Махмутович - к.и.н., старший научный сотрудник, Институт этнологических исследований им. Р.Г. Кузеева Уфимского федерального исследовательского центра РАН (450078 Уфа, ул. Аксакова, 7). Эл. почта: ildargab@yandex.ru

* Работа выполнена по гранту РФФИ «Централизация, этнический фактор и электоральные процессы в регионах России», проект №20-011-00444A 
в период проведения последних советских переписей населения 1979 и 1989 гг., а также двух постсоветских переписей - 2002 и 2010 гг., свидетельствует о том, что особенности текущей политики всегда влияли на численное соотношение проживающих в республике народов, прежде всего, татар и башкир. Здесь переписи создают чрезмерную межэтническую напряженность, а объектом статистических манипуляций становятся пограничные зоны расселения этнических групп. Одной из таких зон является обширная территория, которая до образования автономных республик входила в состав трех уездов Уфимской губернии - Белебеевский, Бирский (ныне это северо-западная Башкирии, меридионально к западу от Уфы) и Мензелинский (ныне восточный Татарстан, к востоку от Набережных Челнов и Елабуги). Именно вокруг «татаро-башкирского вопроса» всякий раз разворачиваются ожесточенные дискуссии, которые выходят за рамки обычного статистического учета население, влияя на текущую политику.

Всесоюзная перепись населения 1989 г. - последняя советская перепись, она проводилась в условиях горбачевской перестройки и демократизации, после известного Пленума ЦК КПСС 1988 г., осудившего перекосы в национальной политике в отдельных регионах СССР, в т.ч. и в Башкирии. Отсутствие административного нажима со стороны местной власти во время переписной кампании привело к значительному росту численности татар и сокращению численности башкир (На пути к переписи 2003; Габдрафиков 2003).

Всероссийская перепись населения 2002 г. - первая постсоветская перепись, по итогам которой произошел резкий всплеск численности титульной этнической группы и обвал численности татар. Всплеск численности башкир и уменьшение численности татар произошел за счет сельского населения западных районов республики (Этнокультурный облик России 2007).

Всероссийская перепись населения 2010 г. - накануне переписи в республике произошла смена власти, текущая политика отразилась и на итогах переписи - последовало заметное уменьшение численности башкир при одновременном росте численности татар. Опять же эта статистическая метаморфоза произошла за счет западных районов Башкирии (Габдрафиков 2011). В контексте подготовки в Башкирии переписи населения, где в качестве чуть ли не главного снова рассматривался переписной вопрос о национальности, следует напомнить, что вплоть до момента смены власти республиканская пропагандистская машина внедряла в общественное сознание тезис о том, что во главе республики обязательно должен быть этнический башкир.

В разгар кампании по подготовке к проведению переписи, в июле 2010 г. в Башкирии (сама перепись проводилась в октябре 2010 г.) Президентом стал Рустэм Хамитов, который обозначил себя как башкир, но прежде в своих анкетных данных писал, что он татарин. Со сменой руководства в Башкирии оправдался прогноз ряда экспертов о том, что это отразится и на переписной кампании, что со стороны региональной власти не будет такого нажима, который мы наблюдали в прежние переписные кампании. Однако подготовка к переписи набрала темп еще при прежнем руководителе Башкирии. Поэтому она до смены республиканской власти напоминала, как и в прошлую перепись 2002 г., политизированную избирательную кампанию. Перепись снова превратилась в важный фактор общественно-политической жизни республики. Прежнее руководство республики перед переписью ставило задачу сохранить «достигнутое», а по возможности «улучшить» показатели и вывести титульную этническую группу по численности на первое место. 
Примерно за год до сроков проведения самой переписи по республиканскому телевидению, радио и печатным СМИ практически ежедневно шла информационная обработка населения республики о том, что исконное население сел и деревень западной Башкирии и восточной Татарии - башкиры, а не татары. Говорилось, что эти населенные пункты остаются преимущественно башкирами, что они и сегодня разговаривают не на татарском, а на северо-западном диалекте башкирского языка.

Татарскими общественными организациями республики подобная информационная политика официальных СМИ была расценена как подготовка общественного мнения к фальсификации во время предстоящей переписи. Они развернули свою борьбу с целью «противостоять оголтелой националистической пропаганде и готовящейся повторной фальсификации».

Вместе с тем, главным отличием ВПН-2010 на территории Башкирии явилось то, что ее окончательные этапы пришлись на смену власти в республике. Это обстоятельство стало ключевым фактором, который повлиял как на ход переписи, так и на ее итоги. Однако полностью избежать давления на процедуру переписи не удалось слишком велика была инерция нажима, который осуществлялся прежней властью.

Проделанный нами анализ данных переписей населения 1989, 2002 и 2010 гг, а также микропереписей 1994 и 2015 гг. по этническому составу населения республики свидетельствует, во-первых, о довольно значительных перепадах в официальной численности этнических групп по результатам больших переписей и, во-вторых, об относительной стабильности показателей микропереписей. Эти статистические зигзаги касаются численного соотношения, прежде всего, татар и башкир в Башкирии (см. табл. 1 и табл. 2).

Таблица 1

\section{Динамика численности основных этнических групп в Республике Башкорто-} стан по данным переписей населения 1989, 2002, 2010 гг.

\begin{tabular}{l|c|c|c|c|c|c}
\hline \multirow{2}{*}{} & \multicolumn{2}{|c|}{1989 г. } & \multicolumn{2}{c|}{2002 г. } & \multicolumn{2}{c}{2010 г. } \\
\cline { 2 - 7 } & Чел. & $\%$ & Чел. & $\%$ & Чел. & $\%$ \\
\hline Все население & 3943113 & 100 & 4104336 & 100 & 4072295 & 100 \\
\hdashline Башкиры & 863808 & 22 & 1221302 & 30 & 1172287 & 29 \\
\hdashline Татары & 1120702 & 28 & 990702 & 24 & 1009295 & 25 \\
\hdashline Русские & 1548291 & 39 & 1490715 & 36 & 1432.906 & 35 \\
\hdashline Другие & 410312 & 11 & 401617 & 10 & 457807 & 11 \\
\hline
\end{tabular}

На октябрь 2020 г. было намечено проведение Третьей Всероссийской переписи населения, однако из-за начавшейся в стране пандемии короновируса COVID-19, сроки ее проведения трижды переносились - сначала на апрель 2021 г., второй раз на сентябрь и затем на октябрь 2021 г. В октябре 2018 г. в Башкирии сменилась власть - прежний глава республики Рустэм Хамитов был отправлен в отставку, а исполняющим обязанности главы РБ стал Радий Хабиров. Между тем местные общественники, а также часть ангажированных ученых-гуманитариев и журналистов снова взялись за активную подготовку к переписи с целью повлиять на ее этностатистические результаты. 
Таблица 2

Этническая принадлежность население Республики Башкортостан, принявшее участие в микропереписях 1994 и 2015 гг.

\begin{tabular}{|c|c|c|c|c|c|c|c|c|}
\hline & \multirow{2}{*}{\multicolumn{2}{|c|}{ 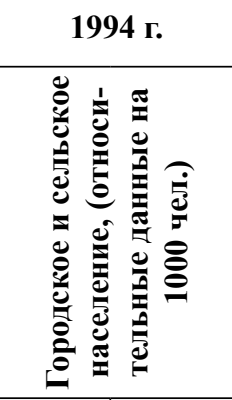 }} & \multicolumn{6}{|c|}{2015 г. } \\
\hline & & & 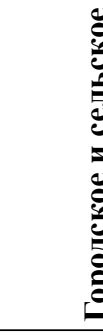 & 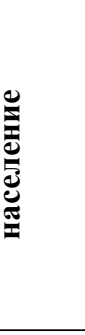 & & & & \\
\hline & Чел. & $\%$ & Чел. & $\%$ & Чел. & $\%$ & Чел. & $\%$ \\
\hline Всего опрошено & 1000 & 100 & 46444 & - & 26501 & - & 19943 & - \\
\hline $\begin{array}{c}\text { Лица, указавшие } \\
\text { национальную } \\
\text { принадлежность }\end{array}$ & & & 46054 & 100 & 26275 & 100 & 19779 & 100 \\
\hline Башкиры & 229 & 22,9 & 10728 & 23,3 & 3756 & 14,3 & 6972 & 35,2 \\
\hline Русские & 390 & 39,0 & 17934 & 38,9 & 13299 & 50,6 & 4635 & 23,4 \\
\hline Татары & 287 & 28,7 & 13727 & 29,8 & 7435 & 29,7 & 5933 & 30,0 \\
\hline $\begin{array}{l}\text { Лица, в перепис- } \\
\text { ных листах кото- } \\
\text { рых не указана } \\
\text { национальная при- } \\
\text { надлежность }\end{array}$ & - & - & 390 & 0,8 & 226 & 0,9 & 164 & 0,8 \\
\hline $\begin{array}{l}\text { Из них отказав- } \\
\text { шиеся отвечать на } \\
\text { вопрос о нацио- } \\
\text { нальной принад- } \\
\text { лежности }\end{array}$ & - & - & 360 & 0,8 & 197 & 0,8 & 163 & 0,8 \\
\hline
\end{tabular}

Несмотря на перенос сроков ВПН-2021, общественные дискуссии вокруг этноязыковых вопросов (о языковой принадлежности татаро-башкирского населения западных районов Башкирии и восточных районов Татарии) начались еще задолго до первой объявленной даты и продолжаются доныне, а непосредственно перед самой переписью они обострились еще более рельефно. Объектом споров снова стали этническая и языковая принадлежность татар и башкир, исторически проживающих в татаро-башкирской пограничной зоне. Однако если в предыдущие переписные кампании противоборствующие стороны обращали свое внимание главным образом на этническую составляющую переписи, мало уделяя внимание языковой стороне, то важнейшей особенностью подготовки предстоящей стал именно ее языковой аспект. Так, весной 2020 г. в республике прошла акция «Башкирский диктант», где наряду 
с литературным языком впервые предлагалось написать текст на так называемом «северо-западном диалекте башкирского языка». Это вызвало негативную реакцию татароязычной общественности республики, а также официального Татарстана. До этого, в октябре 2019 г. в России прошла акция «Татарский диктант», которая в Башкирии встретила заметное сопротивление со стороны республиканских властей.

Анализ этнодемографических процессов за последние три десятка лет свидетельствует о том, что этнические группы в Башкирии имеют разные показатели естественного и механического движения населения, которые, безусловно, влияют на их численное соотношение в общей доле жителей республики. Например, из-за относительно низких показателей естественного прироста (соотношения рождаемости и смертности), а также заметного превышения доли выбывших за пределы региона над долей прибывших, прогнозируется дальнейшее сокращение абсолютной и относительной численности русских в республике. Так, численность русских за период с 1989 по 2010 гг. снизилась более чем на 115 тыс. чел. (при этом за указанный период общая численность населения республики выросла на 129 тыс. чел.), а их удельный вес в общей доле населения упал с 39,3\% до 35,2\%. При этом самое значительное сокращение русского населения наблюдалось в столице республики, где они за 20 лет потеряли около 100 тыс. чел. (Национальный состав... Ч. 1 2013; Национальный состав... Ч. 2 2013).

Таким образом, статистика этнического состава населения по итогам предстоящей переписи вновь в значительной степени может оказаться зависимой от позиции руководства республики, от его возможных установок на получение «нужных цифр», а не от объективных показателей этнодемографии. Поэтому ответственным за перепись лицам на уровне федеральной и региональной властей, Росстата следует детально продумать механизмы по минимизации влияния субъективного фактора на проведение переписи, наказании лиц, пытающихся вмешаться в ее ход и итоги.

В Башкирии переписные кампании с каждым разом создают чрезмерную межэтническую напряженность как в самой республике, так и на межреспубликанском уровне, а объектом этностатистических споров становятся пограничные зоны расселения этнических групп. Накануне предстоящей переписи снова резко участились публикации в СМИ, словесные баталии в социальных сетях, которые создают негативный информационный фон вокруг этнических аспектов переписной кампании.

Пример татар и башкир на территории западной Башкирии свидетельствует о том, что между ними нет этнокультурных различий, невозможно провести языковую, культурную границы, водораздел проходит только на уровне самосознания, которая может быть двойственной или размытой. Однако на республиканском уровне есть конкуренция между активными блогерами, этноактивистами, которые часто будируют вопрос об этнической принадлежности населения татаро-башкирской пограничной зоны.

На проблему должны обратить более пристальное внимание руководители Башкортостана и Татарстана, совместно предложив региональным и муниципальным чиновникам, ответственным за национальную политику, широкой общественности позитивную альтернативу в противовес сложившемуся в последние годы негатив- 
ному информационному фону, т.к. состояние межнациональных отношений - это вопрос в том числе и качества управления.

Необходимо минимизировать роль региональных информационного, идеологического и административного ресурсов на процесс этнического самоопределения людей, предоставив людям самим определиться с их этнической принадлежностью, а не решать за них, кто они по национальности.

До сих пор эскалации межэтнической напряженности в определенной степени способствовал сам инструментарий переписи, который не учитывал, что человек может иметь двойственную или нечеткую этническую идентичность. Поэтому совершенно оправдано принятое Росстатом решение о том, что во время предстоящей переписи можно будет указывать несколько национальностей (первая национальность, вторая, третья), а также несколько языков. Это не приведет к размыванию этнической идентичности, но поможет в определенной степени снять напряженность, позволит избежать ненужной политизации, а ученым даст возможность глубже анализировать этнокультурные процессы.

\section{Источники и материалы}

Национальный состав Ч. 1 - Национальный состав и владение языками, гражданство населения Республики Башкортостан по данным Всероссийской переписи населения 2010 года: статистический сборник / отв. за вып.: И.Б. Утяшева. В 2 ч. Ч. 1. Уфа: Башкортостанстат, 2013. $193 \mathrm{c}$.

Национальный состав Ч. 2 - Национальный состав и владение языками, гражданство населения Республики Башкортостан по данным Всероссийской переписи населения 2010 года: статистический сборник / отв. за вып.: И.Б. Утяшева. В 2 ч. Ч. 2. Уфа: Башкортостанстат, 2013. $189 \mathrm{c}$.

\section{Научная литература}

Габдрафиков И.М. Перепись населения в Башкирии: материалы полевой этнографии // Этнография переписи-2002 / под ред. Е. Филипповой, Д. Ареля, К. Гусеф. М.: ОАО «Авиаиздат», 2003. C. $101-134$.

Габдрафиков И.М. Башкортостан: как готовили перепись в условиях смены власти // Этнологический мониторинг переписи населения / под ред. В.В. Степанова. М.: ИЭА РАН, 2011. C. 179-189.

Степанов В.В., Тишков В.А. (отв. ред.) Этнокультурный облик России. Перепись 2002 г. М.: Наука, 2007. $516 \mathrm{c.}$

Тишков В.А. (отв. ред.) На пути к переписи. М.: ОАО «Авиаиздат», 2003. 528 с.

Gabdrafikov, Ildar $M$.

\section{Population Censuses in the Tatar-bashkir Border Region: Politicization of Ethnostatistics}

DOI: $10.33876 / 2311-0546 / 2021-3 / 17-23$

The article analyzes the ethnic statistics in the Republic of Bashkortostan based on the data of the last three population censuses of 1989, 2002 and 2010, and the micro-census of 2015. It analyzes demographic, informational, administrative, ideological factors that affect the results of the censuses. It is concluded that there are no ethnocultural differences between Tatars and Bashkirs in western Bashkiria, while the watershed exists only at the level of people's self-consciousness. However, the censuses themselves always create excessive 
interethnic tension and the escalation of negative stereotypes. There is also an information confrontation in the media and social networks between the parties, which resembles the eve of election campaigns when certain socio-political forces are fighting for votes. Of course, this information confrontation during the censuses has a negative impact on the interethnic climate in the republic as a whole. It is exactly because of excessive politicization and the use of administrative resources that the official census results do not adequately reflect the objective ethnic picture and ethnodemographic processes in the region. The article suggests specific practical measures to mitigate tension during the census.

Keywords: ethnic statistics, census, ethnic groups, ethnic borders, National identity, population movement

For Citation: Gabdrafikov, Ildar M. 2021. Population Censuses in the Tatar-bashkir Border Region: Politicization of Ethnostatistics. Herald of Anthropology (Vestnik Antropologii) 3: 17-23.

Author Info: Gabdrafikov, Ildar M. - PhD (Hist.), Senior Researcher, Rail G. Kuzeev Institute of Ethnic Studies of Ufa Federal Research Center Russian academy of Sciences (Ufa, RF). E-mail: ildargab@yandex.ru

Funding: The study was carried out with the financial support of the Russian Foundation for Basic Research, scientific project No. 20-011-00444A

\section{References}

Gabdrafikov, I.M. 2003. Perepis' naseleniya v Bashkirii: materialy polevoĭ ètnografii [Census ща population in Bashkiria: materials of field Ethnography]. In Filippova, E., Ariel, D., and K. Guseff (eds.). Etnografiya perepisi-2002 [Ethnography of the census - 2002], 101-134. Moscow: OAO "Aviyaizdat".

Gabdrafikov, I.M. 2011. Bashkortostan: kak gotovili perepis' v usloviyakh smeny vlasti [Bashkortostan : how the census was prepared in the conditions of the change of power]. In Stepanov, V.V. (ed.). Etnologicheskii monitoring perepisi naseleniya [Ethnological monitoring of the population census], 179-189. Moscow: IEA RAN.

Stepanov, V.V., Tishkov, V.A. (eds.). 2007. Etnokul'turny oblik Rossii. Perepis'2002 g. [The ethnocultural image of Russia. Census - 2002]. Moscow: Nauka.

Tishkov, V.A. (ed.). 2003. Na puti kperepisi [On the way to the census]. Moscow: OAO “Aviyaizdat”. 